\title{
Effect of Good Corporate Governance and Investor Protection on Real Activity Manipulation (RAM) in Three ASEAN Countries (Indonesia, Malaysia, and Singapore)
}

\author{
Muhammad Andryzal Fajar ${ }^{1}$, Dhyah Setyorini ${ }^{2}$ \\ (andryzal_fajar@uny.ac.id ${ }^{1}$,dhyah_setyorini@uny.ac.id ${ }^{2}$ ) \\ Universitas Negeri Yogyakarta, Indonesia ${ }^{1,2}$
}

\begin{abstract}
This research aims to investigate the Good Corporate Governance and Investor Protection to Real Activity Manipulation. This research data are 1,202 manufacturing financial statements listed on the stock exchange in 2017 in three ASEAN countries (Indonesia, Malaysia, and Singapore) obtained from the OSIRIS database, which was selected by a purposive sampling technique. The data analysis technique used is the multiple linear regression analysis tests. This study shows that the Audit Committee, Managerial Ownership, and Board of Commissioners Composition have no significant effect on Real Activity Manipulation. In contrast, Board of Commissioners Size and Investor Protection have a impact on Real Activity Manipulation.
\end{abstract}

Keywords: Audit Committee, Managerial Ownership, Board of Commissioners Composition, Board of Commissioners Size, Investor Protection, Real Activity Manipulation.

\section{Introduction}

Company management is required to describe the actual performance, even the best financial condition of the company. It is related to efforts to maintain the company's position in the industry and management awards. In the end, the company's management unwittingly manipulated financial reporting through earnings management practices so that the company's performance looks good [1]. Managers' opportunistic behavior to practice earnings management is done by choosing specific accounting methods or policies to increase profits or reduce profits [2]. According to Graham et al. [3], top management is more willing to engage in real earnings management practices rather than accrual management practices to meet earnings targets. Roychowdhury [4] states that the phenomenon of earnings management carried out by companies in addition to accrual-based earnings management is also the practice of real activities.

According to Roychowdhury [4], the shift from accrual to real earnings management is motivated by a number of factors. To begin, accrual earnings management is more likely to attract auditors and regulators' attention than accurate decision-making. Second, managers who rely solely on accrual earnings management will be exposed if the year-end gap between manipulated earnings and the desired profit target exceeds the amount that can be controlled through accrual earnings management after the fiscal period ends [4][5]. 
Earnings management through real activity manipulation is earnings management that starts from normal operating practices, motivated by the desire of managers to trick stakeholders into believing that some financial statement objectives have been achieved through normal functional activities. Real earnings management may have a higher long-term cost to stakeholders than accrual earnings management, as real earnings management has a detrimental effect on cash flow and firm value over time [4][6].

Good corporate governance promotes healthy competition and a favorable business climate. As a result, it is critical for businesses in Indonesia to practice good corporate governance in order to foster long-term economic growth and stability. The implementation of Good Corporate Governance is also estimated to boost the government's efforts to compel companies to adhere to Good Corporate Governance [5]. The purpose of implementing Good Corporate Governance principles is to achieve effective and efficient company performance through management alignment. Harmonization of company management is expected to reduce earnings management practices. Exemplary corporate governance implementation requires several tools as indicators of whether or not Good Corporate Governance has been achieved. Good Corporate Governance in this study includes Managerial Ownership, Composition of the Board of Commissioners, Size of the Board of Commissioners, and the Audit Committee.

In addition, Good Corporate Governance is needed for Investor Protection to protect investors' rights in a country against errors and fraud that occur in a company that goes public. Investor protection is a significant determinant of earning management activities. Investor protection is the right regarding accounting statements and regulations, which provide investors with the information they need to test other rights [7]. This insight shows that the pervasiveness of earnings management increases in private control gains and decreases in investor protection. Based on the description stated above, this study analyzes the effect of Good Corporate Governance and investor protection on Real Activity Manipulation.

\section{Literature Review}

\subsection{Agency Theory}

Agency theory emerged driven by several research results by Jensen and Meckling [8], which discussed agency relationships using the analysis of a contract between agents and principals, so they are famous for being the originators of agency theory. According to Jensen and Meckling [8], agency relationships exist when one or more additional individuals are referred to as agents. The principle delivers a service and empowers the agent to act on the principal's behalf. The agency theory can be used to justify management's practice of revealing accounting and non-accounting information to principals, shareholders, creditors, potential investors, and other interested parties. The principal-agent relationship frequently involves a conflict of interest, which results in information asymmetry.

Asymmetry in information occurs when management is more adept at controlling information than owners and shareholders are. Individuals act to maximize their own selfinterest, according to agency theory. The agent's information asymmetry will encourage the agent to conceal some information that is not known to the principal. So that in this kind of situation, the principal is often at a disadvantage [9]. Eisenhardt [10] explains that the purpose of agency theory is to resolve the problem of conflict between agents (management) and principals (owners). 


\subsection{Real Activity Manipulation}

Real activity manipulation is part of earnings management practice. Real activity manipulation is a deviation through regular operational procedures, motivated by managers who want to lie to stakeholders to believe the financial statements provided and show the causes of changes in the company's operating activities [4].

According to a survey conducted by Graham et al. [3], financial executives expressed a greater desire to manipulate earnings via real activity manipulation than through accrual manipulation. Managers use this method for at least two reasons. To begin, accrual manipulation is more likely to influence auditors or regulatory security than it is to influence accurate pricing and production decisions. Second, accrual manipulation carries a higher risk. Manipulation of real-world activities has the potential to diminish the value of a business. It may occur as a result of actions taken in the current year to increase profits having a negative effect on future cash flows.

Measurement of real activity manipulation in the Roychowdhury [4] model focuses on three calculation components, as follows:

a. Abnormal cash flow operation

Abnormal cash flow operation is the manipulation of profits by the company through operating cash flows. The company will have a lower cash flow than the average level. The estimated residual value of operating cash flows is the value of abnormal operating cash flows.

b. Abnormal production cost

Abnormal production cost is earnings management activities carried out by manipulating the company's production costs. The company will have higher production costs than its average level. The residual value of production costs is abnormal production costs.

c. Abnormal discretionary expenses

Abnormal discretionary expenses are profit manipulation activities through research and development costs, advertising costs, sales, administration, and general costs. The residual value obtained from discretionary costs is the value of abnormal discretionary expenses.

\subsection{Good Corporate Governance}

Corporate governance is a mechanism that can be used to ensure that financial suppliers or owners of company capital obtain returns from activities carried out by managers. In other words, how the company's financial suppliers exercise control over managers. Additionally, corporate governance provides a structure for establishing a company's goals and determining performance monitoring techniques. Implementing a corporate governance mechanism is expected to reduce managers' desire to manipulate reported performance in order to ensure that it accurately reflects the company's economic condition [2].

The Study Team of the Ministry of Finance of the Republic of Indonesia [11] has conducted a comprehensive study of Good Corporate Governance guidelines in three member countries of The ASEAN Capital Market Forum (ACMF), namely: Indonesia, Malaysia, and Singapore. Several aspects discussed in the study and relevant to this research are as follows:

a. Methods of Applying Guidelines and Sanctions

The implementation of Good Corporate Governance guidelines by listed companies such as stock exchanges in Malaysia, Singapore, Thailand, and the Philippines is to comply and 
explain (companies are expected to apply all aspects of the guidelines). Meanwhile, in Indonesia, the implementation of Good Corporate Governance guidelines is not regulated by either the stock exchange or capital market authorities, so there is no obligation for companies to implement these guidelines (voluntarily). However, if the company does not implement the GCG aspect, the policies explain this matter.

b. Independent Commissioner

In general, the composition of independent commissioners belonging to ACMF member countries is one-third of the total number of commissioners, or at least three people. However, only the Philippines determines the number of independent commissioners to be less, namely at least two people or $20 \%$ of the total number of the Board of Commissioners.

c. Directors

The board of directors' composition is generally not quantified in the Good Corporate Governance Guidelines. However, the number of board members must be proportionate to the complexity of the business, taking decision-making effectiveness into account. In a country with a single board system (in which the board of directors and the board of commissioners have the same functions), the composition of the board of directors includes the board of commissioners as a unit. Meanwhile, in countries that use a two-board system (separating the functions of the board of directors and the board of commissioners), the composition of the board of directors and the board of commissioners are separated, with the composition or number of directors covering only the management function of the company.

Countries use the one board system (Malaysia and Singapore) separation of roles and responsibilities by separating the roles and functions of the board chairman (generally as independent commissioners) and the Chief Executive Director. Separation to achieve a balance of power, increase accountability and provide greater capacity for independent decision-making. Both positions are required to be held by two different individuals.

d. Establishment of the Committee by the Commissioner

The existence of independent commissioners on the board of commissioners and the committees formed is essential. Generally, the guidelines will only regulate the minimum quantity, composition, capability, and integrity requirements that must be met. The design of audit committee members required by Indonesia, Malaysia, Singapore, and the Philippines is a minimum of three people. At the same time, Thailand does not determine the minimum number of audit committees. In the audit committee chairman, Malaysia does not explicitly require that the audit committee chairman is an independent commissioner. Unlike Malaysia, the other four countries require otherwise. Generally, the educational background necessary for audit committee members is accounting or finance. Some of the committees recommended in the GCG guidelines from the three countries are the nomination committee and the remuneration committee. Two additional committees are recommended in Indonesia, namely the risk policy committee and the corporate governance policy committee.

\subsection{Investor Protection}

Investor protection is a right regarding accounting statements and regulations, which provide investors with the information they need to test other rights [7]. Many capitals or financial market developments create better external financing opportunities for companies because the legal system protects investors by giving them disciplinary rights. 
Different laws and regulations regarding investor protection can come from various sources, including corporate, security, bankruptcy, takeover, legal competition, and capital market regulations and accounting standards. The implementation of the law is a crucial part of this content. In some countries, rules and regulations are partly part of market regulation, part courts, partly to their market participation. Therefore, all outside investors, whether small or large, all need the protection of investor rights [12].

Investor protection is calculated through five dimensions adapted from House et al. [13]. The five dimensions are:

a. Board independence

The board of directors has a vital role as an independent supervisor of management activities and a protector of stakeholders' wealth. The separate part of the board of directors can reduce interest problems that arise from differences in interests between shareholders and company management through monitoring management behavior.

b. Enforcement of securities law

Enforcement of legal protection can prevent profit manipulation by internal parties in increasing profits on company shares.

c. Protection of minority shareholder rights

Countries with lax protection for minority shareholders provide an important impetus for managers to make financial fraud. According to La Porta et al. [12], countries with strong investor protection will increase minority share rights and resolve conflicting interests between internal and external parties.

d. Enforcement of accounting and auditing standards

The application of accounting and auditing standards correctly provides a narrow space for management and auditors to make mistakes in financial statements. High-quality accounting standards reduce analytical errors in reports.

e. Judicial independence

A country may have a well-functioning legal system but weak enforcement of accounting regulations. However, it would be difficult to imagine a situation where the legal system is flawed, but enforcement of accounting regulations is substantial.

The five dimensions have a value range of 1 to 7 , where the number 7 indicates the high value of the investor protection dimension in that country. The value of the investor protection dimension is sourced from the World Economic Forum (WEF), which is then aggregated to obtain the value of investor protection for each country [13].

\subsection{The Effect of Audit Committee on Real Activity Management}

The audit committee has performed admirably in assisting the board of commissioners in carrying out its duties and functions and acting independently in carrying out its responsibilities to prevent the company from improving its earnings management practices [5]. The board of commissioners establishes the audit committee to oversee the company's management. The audit committee's existence is critical to the management of the company because it is one of the control systems that connects the shareholders and board of commissioners to the management [2].

H1: Audit Committee effect on Real Activity Management in Three ASEAN Countries (Indonesia, Malaysia, and Singapore) 


\subsection{The Effect of Managerial Ownership on Real Activity Management}

According to Boediono [14], a certain percentage of management ownership tends to influence earnings management actions. According to this study, the higher the managerial ownership structure, the more likely management will act in the shareholders' best interests. Kusumawati et al. [2] provide empirical evidence that managerial Ownership can limit managers to perform earnings management. Organizational objectives are in line with shareholder goals, so the supervision of the company will be more effective and make managers more careful in carrying out earnings management practices.

H2: Managerial Ownership effect on Real Activity Management in Three ASEAN Countries (Indonesia, Malaysia, and Singapore)

\subsection{The Effect of Board of Commissioners Composition on Real Activity Management}

The growing number of independent board members in a company necessitates greater transparency in financial reporting. This means that the greater the proportion of independent commissioners in a business, the more earnings management can be reduced [2]. The board of directors' composition is one of the characteristics that correlates with the content of earnings information. The composition of the board of commissioners, through its supervisory function, can influence management in preparing financial reports, resulting in a high-quality earnings report [5]. Hidayanti et al. [5] investigated the relationship between corporate governance practices and earnings management. The findings indicated that the proportion of independent commissioners had a beneficial effect on the company's earnings management.

H3: Board of Commissioners Composition effect on Real Activity Management in Three ASEAN Countries (Indonesia, Malaysia, and Singapore)

\subsection{The Effect of Board of Commissioners Size on Real Activity Management}

Chtorou et al. [15] discovered that the size of the board of commissioners has a significant negative effect on earnings management, as measured by the modified Jones model. This indicates that the fewer commissioners on the board, the more earnings management acts, as fewer commissioners allow management to dominate the organization in carrying out its role. Kusumawati et al. [2]demonstrate empirically that the size of the board of commissioners has an effect on company's earnings management practices. A positive sign indicates that an effect has occurred. This indicates that an increasing number of members of the board of commissioners have maintained their current earnings management practices.

H4: Board of Commissioners size effect on Real Activity Management in Three ASEAN Countries (Indonesia, Malaysia, and Singapore) 


\subsection{The Effect of Investor Protection on Real Activity Management}

Conflicts of interest between shareholders/investors and company managers often occur in the business world. External parties, in this case, namely investors, have the interest to benefit from the profits obtained by the company through the distribution of dividends. A reasonable profit also shows the company's condition is in good condition. On the other hand, the company's internal parties, in this case, are company managers who have an interest in showing good company performance for a purpose or even personal benefit. The presentation of financial statements is one of the company's performance measurement tools in a period given to internal parties. Managers are required to present optimal profits to provide good reports to shareholders and attract new investors. Therefore, many managers manipulate earnings to present good company financial statements.

Leuz et al. [7] found that countries with strong legal protections reduce the incentive for managers to perform earnings management through accrual manipulation. Therefore, the researcher assumes that managers prefer to manipulate earnings through actual activity manipulation rather than accrual manipulation with strong investor protection. Accrual manipulation is easier to detect, while real activity manipulation can be a subjective activity, and the auditor may have limited ability to ensure manager decisions related to real activites.

H5: Investor protection effect on natural activity management in Three ASEAN Countries (Indonesia, Malaysia, and Singapore)

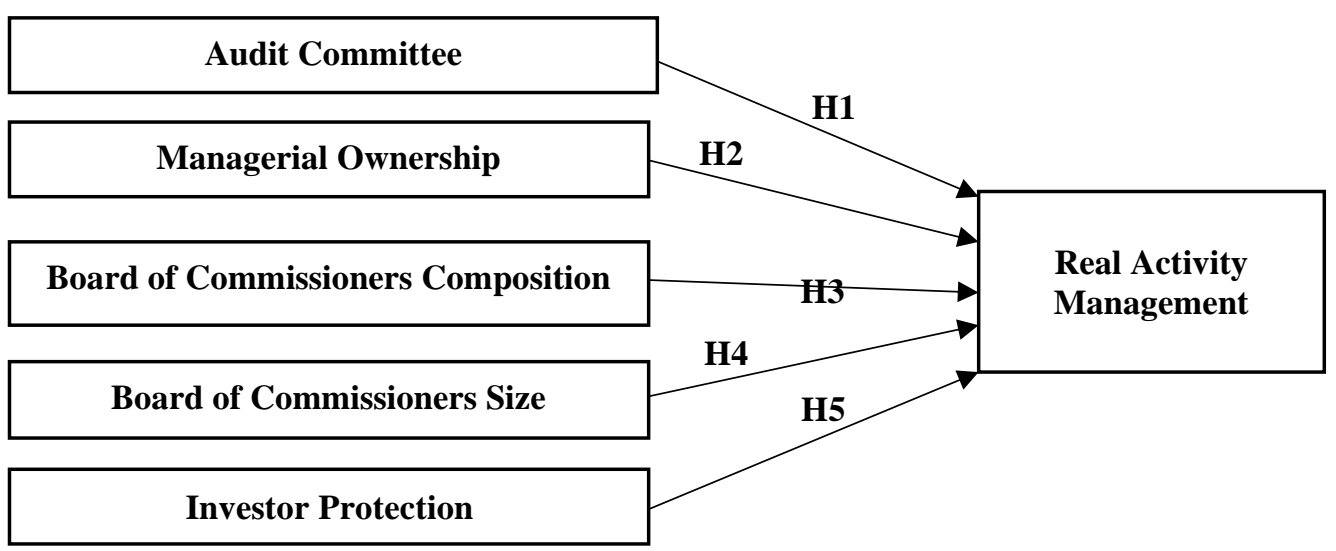

Fig. 1. Research paradigm

\section{Research Methods}

\subsection{Research Design}

This study uses a quantitative approach based on secondary data obtained through an official database, then analyzed using statistical calculations. This research was conducted by taking secondary data obtained through financial reports and investor protection index through the World Economic Forum website and other relevant sources. 


\subsection{Population and Sample}

The population used in this study are companies in member countries of The ASEAN Capital Market Forum (ACMF) listed in the OSIRIS database. The countries of Indonesia, Malaysia, and Singapore were then selected as samples. The three countries have almost similar Good Corporate Governance policies.

Sampling was carried out in this study with the non-probability sampling method, the purposive sampling method. Purposive sampling or sampling-based on specific considerations involves selecting subjects who are in the most advantageous place or in the best position to provide the necessary information [16].

The considerations used in this study are as follows:

a. The sample is companies in Indonesia, Malaysia, and Singapore, because these three countries have almost similar good corporate governance guidelines compared to the other two countries. The purpose of the three-country sampling is also to ensure equality of the sample in performing statistical tests.

b. Not included in the type of banking industry, financial institutions, and State-Owned Enterprises (regulated industries)

c. financial reporting period in 2017

d. Complete financial report information

\subsection{Operational Definition and Measurement of Research Variables 3.3.1.Real Activity Manipulation}

Real activity manipulation is part of earnings management practice. Real activity manipulation is a deviation through everyday operational practices, motivated by managers who want to lie to stakeholders to believe the financial statements provided and show the causes of changes in the company's operating activities [4].

The value of actual activity manipulation is obtained from the equation that has been developed by Roychowdhury [4]. In calculating the real activity manipulation, the classical assumption analysis was not carried out first in the regression test. It is because the researcher will only take the standardized value obtained from the equation. This study will use three main components in the calculation of real activity manipulation as follows:

a. Abnormal cash flow operation (Abn_CFO)

$\mathrm{CFO}_{\mathrm{t}} / \mathrm{A}_{\mathrm{t}-1}=\alpha_{0}+\alpha_{1}\left(1 / \mathrm{A}_{\mathrm{t}-1}\right)+\beta_{1}\left(\mathrm{~S}_{\mathrm{t}} / \mathrm{A}_{\mathrm{t}-1}\right)+\beta_{2}\left(\Delta \mathrm{S}_{\mathrm{t}} / \mathrm{A}_{\mathrm{t}-1}\right)+\varepsilon_{\mathrm{t}}$

b. Abnormal production cost (Abn_Prod)

PROD $_{t} / A_{t-1}=\alpha_{0}+\alpha_{1}\left(1 / A_{t-1}\right)+\beta_{1}\left(S_{t} / A_{t-1}\right)+\beta_{2}\left(\Delta S_{t} / A_{t-1}\right)+\beta_{2}\left(\Delta S_{t-1} / A_{t-1}\right)+\varepsilon_{t}$

c. Abnormal discretionary expenses (Abn_Disexp)

$\operatorname{DISEXP} / A_{\mathrm{t}-1}=\alpha_{0}+\alpha_{1}\left(1 / \mathrm{A}_{\mathrm{t}-1}\right)+\beta\left(\mathrm{S}_{\mathrm{t}-1} / \mathrm{A}_{\mathrm{t}-1}\right)+\varepsilon_{\mathrm{t}}$

Chi et al. [17] stated that real activity manipulation is a standardized amount obtained from the three components' regression equation. The following is the calculation formula for real activity manipulation :

-standardized Abn_CFO + standardized Abn_Prod - standardized Abn_Disexp 


\subsubsection{Good Corporate Governance (GCG)}

Corporate governance is a mechanism that can reassure investors that they will earn a profit on their investment. Corporate governance is concerned with the extent to which investors believe managers will benefit them and the extent to which investors exercise control over managers.

Good Corporate Governance indicators are as follows:

a. Audit Committee

The board of commissioners forms the audit committee to carry out the task of supervising the management of the company. The existence of the audit committee is one of the controls in the company that connects the shareholders and the board of commissioners to the management. The Audit Committee is measured based on the company's percentage of the independent audit board [2] [5].

b. Managerial Ownership

Boediono [14] provides empirical evidence that the motivations of managers as shareholders and those not as shareholders are different. Share ownership owned by a manager will influence decision-making in determining accounting policies and methods to be applied in the company. Managerial Ownership is measured based on the percentage of shares owned.

c. Board of Commissioners Composition

Through its supervisory function, the composition of the board of commissioners is one of the characteristics associated with the information content of earnings. The board of commissioners' composition is quantified by the percentage of the board owned by the company [5].

d. Board of Commissioners Size

The size of the Board of Commissioners is determined by the number of board members in the company. This amount is disclosed and presented in the company's financial statements' notes [5].

\subsubsection{Investor Protection}

Investor protection is the right regarding accounting statements and regulations, which provide investors with the information they need to test other rights [7]. Investor protection is calculated through 5 dimensions: board independence, enforcement of securities law, protection of minority shareholder rights, enforcement of accounting and auditing standards, and judicial autonomy [13]. 


\section{Results and Discussion}

\subsection{Research Result}

This study uses annual report data from 2,866 companies listed on the Stock Exchange in three ASEAN countries: Indonesia, Malaysia, and Singapore. The data was obtained through the OSIRIS database with the 2017 financial reporting period. The company data in this study were only companies outside of banking companies and financial institutions. However, from this number, 1,012 data did not meet the research criteria and 652 outliers. Based on these results, 1,202 company financial statement data can be processed further (see table 1).

Table 1. Data of Research

\begin{tabular}{|c|c|}
\hline Description & Total \\
\hline Data & 2.866 \\
\hline Data that does not meet the criteria & $(1.012)$ \\
\hline Outlier Data & $(652)$ \\
\hline Data used in research & 1.202 \\
\hline
\end{tabular}

The distribution of company data in this study can be described in Figure 2 below.

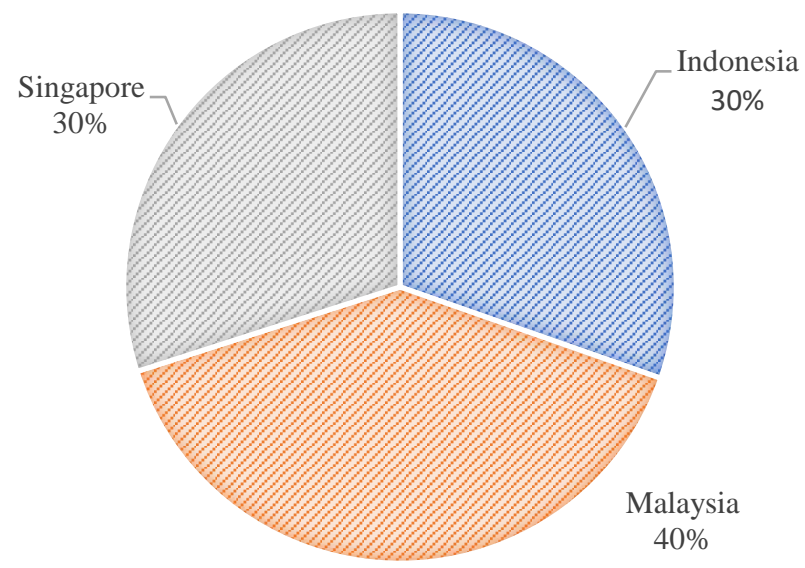

Fig. 2. Distribution of Company Data

Based on Figure 2, there are $365(30 \%)$ company data from Indonesia, $477(40 \%)$ company data from Malaysia, and $360(40 \%)$ data from Singapore. Figure 2 also explains that most of the data is obtained from Malaysia because Malaysia has more companies outside banking and other financial institutions than the other two countries. 
Before further analysis, the data in this study will go through the classical assumption test as a prerequisite for performing multiple regression analysis and testing the hypothesis of this study using multiple regression.

Table 2. Multiple Regression Analysis

\begin{tabular}{lrrr}
\hline \multicolumn{1}{c}{ Variable } & $\begin{array}{c}\text { Standardized } \\
\text { Coefficients }(\mathbf{B})\end{array}$ & t count & Sig. \\
\hline (Constant) & $-0,020$ & 2,447 & \\
Audit Committee & $-0,021$ & $-0,020$ & 0,483 \\
Managerial Ownership & $-0,005$ & $-0,005$ & 0,470 \\
Composition BoC & $-0,127$ & 0,127 & 0,025 \\
Size BoC & $-0,085$ & $-0,085$ & 0,038 \\
Investor Protection & $=$ & 0,102 & \\
\hline R & $=$ & 0,010 & \\
R Square & $=$ & 2,490 & \\
F count & $=$ & 0,030 & \\
Sig. F & $=$ & 0,05 & \\
Alpha $(a)$ & $=$ & 1.202 & \\
N & & & \\
\hline
\end{tabular}

Source: Primary data processed

Table 2. describes the test results between the independent variables (audit committee, managerial ownership, composition of the board of commissioners, size of the board of commissioners, and investor protection) to the dependent variable (actual activity manipulation).

\subsection{Discussion}

\subsubsection{Audit Committee on Real Activity Management}

The effect of the audit committee on real activity management can be seen in Table 2, which shows a significance value of 0.483 . This value means that the audit committee does not affect the real activity management variable. Research by Hidayanti et al. [5] shows that the audit committee does not affect real activity management. There is no effect because establishing an audit committee by the company is mandatory against existing rules. The audit committee's role in carrying out its duties and functions has not been maximized. This analysis supports Susanto and Pradipta's findings [18]. The Audit Committee is an external party to the company that lacks information related to actual activities in the company.

\subsubsection{Managerial Ownership on Real Activity Management}

The effect of managerial ownership on real activity management can be seen in Table 2, which shows a significance value of 0.470 . This value means that managerial ownership does not affect the real activity management variable. The greater managerial ownership does not change opportunistic attitudes and behavior towards the practice of real activity manipulation. The administrative ownership structure, which is insignificant in number, can be said that the management cannot move freely in determining policies and making decisions like shareholders. The results of this study are different from Agustia [19] and Susanto et al. [18]. 
Managers who own shares in their companies tend to take policies to manage earnings related to the wishes of investors. For example, increasing profits generate investor interest and raises the company's stock price.

\subsubsection{Board of Commissioners Composition on Real Activity Management}

The effect board of commissioners' composition on real activity management can be seen in Table 2, which shows a significance value of 0.927 . This value means that the board of commissioners' piece does not affect the real activity management variable. The study results are consistent with the research of Hidayant [5], and Susanto et al. [18] showed no effect board of commissioners composition on actual activity manipulation. The number of commissioners has no effect on the real earnings management action. The findings of this study contradict those of Kusumawati et al. [2] and Jao et al. [20], which indicated that the composition of the board of directors has a detrimental effect on real activity manipulation.

\subsubsection{Board of Commissioners size on Real Activity Management}

The effect of board of commissioners size on real activity management can be seen in Table 2, which shows a significance value of 0.025 . This value means that the size of the board of commissioners affects the real activity management variable. The study results indicate that the number of existing boards of commissioners affects the behavior of managers towards actual activity manipulation control activities in the company. The size of the board of commissioners is a determining factor for the company's management. This study is inconsistent with the research of Kusumawati et al.[2] and Boediono [14].

\subsubsection{Investor Protection on Real Activity Management}

The effect of investor protection on real activity management can be seen in Table 2, which shows a significance value of 0.038 . This value means that investor protection affects the real activity management variable. Research shows that Investor protection involves real activity manipulation. Investor protection is seen from 5 dimensions, namely the board of directors' independence, enforcement of legal safety, security of minority shares, enforcement of accounting \& auditing standards, and judicial autonomy [13]. The board of directors plays an independent supervisory role and minimizes conflict of interest between shareholders and management. Enforcement of legal protection can prevent profit manipulation. Protection of minority shares can reduce problems of external and internal interests. Applying quality accounting standards can eliminate fraud for management to commit fraud an independent legal system to enforce good law. 


\section{Conclusion}

The result of this study, as follows. Audit committee has no effect on the real activity management, managerial ownership has no effect on the real activity management and board of commissioners composition has no effect on the real activity management. Size of the board of commissioners affects the real activity management and investor protection affects the real activity management.

Some suggestions can be given based on the results of the analysis of this study. The culture of Good Corporate Governance in each country is different. The differences in GCG can be used for the development of further research for other countries. Several countries have significantly upgraded their investor protection systems in order to facilitate the implementation to IFRS. Variables at the company level frequently vary in a systematic manner across countries. For instance, government ownership, family shareholders, and institutional ownership.

\section{References}

[1] E. Moazedi and E. Khansalar, "Earnings Management and Audit Opinion," Int. J. Econ. Financ., vol. 8, no. 4, p. 113, Mar. 2016, doi: 10.5539/ijef.v8n4p113.

[2] E. Kusumawati, R. Trisnawati, and A. Mardalis, "Pengaruh Corporate Governance Terhadap Manajemen Laba Riil,” Pros. Semin. Nas. Int., vol. 0, no. 0, 2015, Accessed: Jul. 05, 2021. [Online]. Available: https://jurnal.unimus.ac.id/index.php/psn12012010/article/view/1555.

[3] J. R. Graham, C. R. Harvey, and S. Rajgopal, "The Economic Implications of Corporate Financial Reporting," J. Account. Econ., vol. 40, no. 1-3, pp. 3-73, Dec. 2005, doi: 10.1016/j.jacceco.2005.01.002.

[4] S. Roychowdhury, "Earnings Management Through Real Activities Manipulation," J. Account. Econ., vol. 42, no. 3, pp. 335-370, Dec. 2006, doi: 10.1016/j.jacceco.2006.01.002.

[5] E. Hidayanti, R. Widjayanti Dahniar Paramita, and S. Tinggi Ilmu Ekonomi Widya Gama Lumajang, "Pengaruh Good Corporate Governance Terhadap Praktik Manajemen Laba Riil Pada Perusahaan Manufaktur," Wiga J. Penelit. Ilmu Ekon., vol. 4, no. 2, pp. 1-16, Sep. 2014, Accessed: Jul. $\quad$ 05, 2021. [Online]. Available: https://ejournal.stiewidyagamalumajang.ac.id/index.php/wiga/article/view/120.

[6] N. R. Boedhi and D. Ratnaningsih, "Pengaruh Kualitas Audit Terhadap Manajemen Laba Melalui Aktivitas Riil," KINERJA, vol. 19, no. 1, p. 84, Feb. 2017, doi: 10.24002/kinerja.v19i1.536.

[7] C. Leuz, D. Nanda, and P. D. Wysocki, "Earnings Management and Investor Protection: An International Comparison," J. financ. econ., vol. 69, no. 3, pp. 505-527, Sep. 2003, doi: 10.1016/S0304-405X(03)00121-1.

[8] M. C. Jensen and W. H. Meckling, "Theory of the firm: Managerial Behavior, Agency Costs and Ownership Structure," J. financ. econ., vol. 3, no. 4, pp. 305-360, 1976, doi: 10.1016/0304405X(76)90026-X.

[9] Nasirwan, "Pengaruh Reputasi Auditor, Penjamin Emisi, Komisaris Independen dan Komite Audit Terhadap Kinerja Perusahaan,” Nov. 2012.

[10] K. M. Eisenhardt, "Agency Theory: An Assessment and Review," Acad. Manag. Rev., vol. 14, no. 1, p. 57, Jan. 1989, doi: 10.2307/258191.

[11] L. Purwanti, E. Sulistyani, N. Puspani, Zulhasni, and R. Fatagar, "Kajian Tentang Pedoman Good Corporate Governance di Negara-Negara Anggota ACMF," 2010.

[12] R. La Porta, F. Lopez-De-Silanes, A. Shleifer, and R. Vishny, "Investor protection and corporate governance," J. financ. econ., vol. 58, no. 1-2, pp. 3-27, Jan. 2000, doi: 10.1016/s0304405x(00)00065-9.

[13] M. N. Houqe, T. van Zijl, K. Dunstan, and A. K. M. W. Karim, "The Effect of IFRS Adoption and Investor Protection on Earnings Quality Around the World," Int. J. Account., vol. 47, no. 3, pp. 333-355, Sep. 2012, doi: 10.1016/j.intacc.2012.07.003. 
[14] G. S. Boediono, "Kualitas Laba: Studi Pengaruh Mekanisme Corporate Governance dan Dampak Manajemen Laba Dengan Menggunakan Analisis Jalur," 2005.

[15] S. M. Chtourou, J. Bedard, and L. Courteau, "Corporate Governance and Earnings Management," SSRN Electron. J., Jul. 2001, doi: 10.2139/ssrn.275053.

[16] U. Sekaran, "Metodologi Penelitian untuk Bisnis. Buku 1, Ed.4." Salemba Empat, 2007, $\begin{array}{lllll}\text { Accessed: } & \text { Jul. } & 05, & 2021 . & \text { [Online]. }\end{array}$ https://openlibrary.telkomuniversity.ac.id/home/catalog/id/8158/slug/metodologi-penelitianuntuk-bisnis-buku-1-ed-4-.html.

[17] W. Chi, L. L. Lisic, and M. Pevzner, "Is Enhanced Audit Quality Associated with Greater Real Earnings Management?," 2010. Accessed: Jul. 05, 2021. [Online]. Available: http://ssrn.com/abstract=1904481http://ssrn.com/abstract=1904481.

[18] Y. K. Susanto and A. Pradipta, "Corporate Governance and Real Earnings Management," Int. J. Business, Econ. Law, vol. 9, no. 1, 2016.

[19] D. Agustia, "Pengaruh Faktor Good Corporate Governance, Free Cash Flow, dan Leverage Terhadap Manajemen Laba," J. Akunt. dan Keuang., vol. 15, no. 1, pp. 27-42, May 2013, doi: 10.9744/jak.15.1.27-42.

[20] R. Jao and G. Pagalung, "Corporate Governance, Ukuran Perusahaan, dan Leverage Terhadap Manajemen Laba Perusahaan Manufaktur Indonesia," ejournal.undip.ac.id, 2011, Accessed: Jul. 05, 2021. [Online]. Available: https://ejournal.undip.ac.id/index.php/akuditi/article/view/4346. 